\title{
Penyakit Alergi lain yang Dialami Anak dengan Asma
}

\author{
Lily Irsa, * Arwin A.P. Akib, ** Syawitri P Siregar, ** Zakiudin Munasir** \\ * Departemen Ilmu Kesehatan Anak FK Universitas SumateraUtara / RS H. Adam Malik Medan \\ ** Divisi Alergi Imunologi Departemen Ilmu Kesehatan Anak FK Universitas Indonesial RS Dr.Cipto \\ Mangunkusumo Jakarta
}

\begin{abstract}
Latar belakang. Perjalanan penyakit alergi memperlihatkan bahwa penyakit alergi saling berhubungan dan tampilannya dapat berubah menurut umur sesuai dengan allergic march. Kondisi alergi pada umumnya berupa rinitis alergi, asma, dan dermatitis atopi yang mempunyai jalur imunopatologi sama.

Tujuan. Untuk mengetahui penyakit alergi yang pernah dialami anak dengan asma.

Metode. Penelitian retrospektif terhadap anak dengan asma di Divisi Alergi Imunologi, Departemen Ilmu Kesehatan Anak FKUI/ RSCM dari Januari 2000 sampai dengan April 2003. Data dicatat dari rekam medik dan dikeluarkan dari penelitian bila data tidak lengkap.

Hasil. Didapatkan 148 pasien asma selama kurun waktu penelitian, terdiri dari 83 laki-laki dan 65 perempuan. Riwayat atopi keluarga terdapat pada 103 anak. Penyakit alergi yang pernah dialami adalah rinitis alergi 39 (26,3\%), dermatitis atopi 34 (23\%), urtikaria 13(8,8\%), dan konjungtivitis $2(1,4 \%)$.

Kesimpulan. Dari penelitian ini didapatkan bahwa penyakit alergi lain yang pernah dialami anak asma adalah rinitis alergi, dermatitis atopi, urtikaria, dan konjungtivitis. (Sari Pediatri 2007; 9(4):259-63).
\end{abstract}

Kata kunci: allergic march, atopi, asma, rinitis alergi, dermatitis atopi

$\mathrm{P}$ enyakit alergi merupakan hasil interaksi antara faktor predisposisi genetik atopi dengan alergen lingkungan dan polutan. Faktor lingkungan memegang peran besar pada sensitisasi awal seseorang yang mempunyai bakat atopi dan akan menentukan perkembangan gejala klinis serta

\footnotetext{
Alamat korespondensi

Dr. Lily Irsa, Sp.A. Bagian Ilmu Kesehatan Anak. FK-USU/RS H Adam Malik, Medan. Jl. Bunga Lau no. 17, Medan 20136.

Telepon: 061-836 0405, 836 0143. Fax. 061-836 1721.
}

derajat penyakit. ${ }^{1}$ Manifestasi alergi rinitis alergi, asma, dan dermatitis atopi mempunyai jalur imunopatologi yang sama. Perjalanan penyakit alergi merupakan konsep yang memperlihatkan bahwa penyakit alergi saling berhubungan dan tampilan alergi dapat berubah menurut umur. ${ }^{2}$

Asma merupakan problem di seluruh dunia dan memberikan beban biaya masyarakat dan sistem pelayanan kesehatan pribadi. Prevalensi yang tinggi memberikan efek terhadap kualitas hidup dan juga beban ekonomi masyarakat. ${ }^{3}$ Rinosinusitis merupakan 
penyakit yang sering bersamaan dengan asma. Rinitis alergi yang bersamaan dengan asma pada anak diperkirakan 17\%-25\%. ${ }^{4}$ Kebersamaan rinitis, sinusitis dengan asma menjadi perhatian dokter pada akhirakhir ini. Para peneliti mulai menyadari bahwa saluran napas atas secara aktif memodulasi fungsi paru melalui beberapa cara yang penting. ${ }^{5}$

Penelitian bertujuan untuk mengetahui penyakit alergi yang pernah terjadi pada anak yang menderita asma.

\section{Metode}

Penelitian merupakan studi deskriptif yang dilakukan di Divisi Alergi Imunologi, Departemen IKA FKUI/ RS Cipto Mangunkusumo Jakarta, dari Januari 2000 sampai dengan April 2003. Data diambil dari catatan medik pasien dengan diagnosis asma.

Data yang dicatat adalah diagnosis penyakit alergi yang pernah diderita pasien selain asma, umur, jenis kelamin, riwayat atopi keluarga, hasil uji kulit tusuk (prick test). Bila data tidak lengkap maka tidak diikutsertakan dalam penelitian.

Diagnosis asma ditegakkan secara klinis. Rinitis alergi secara klinis didefinisikan sebagai gangguan fungsi hidung yang terjadi setelah pajanan alergen melalui inflamasi yang diperantarai oleh $\operatorname{IgE}$ pada mukosa hidung dengan gejala yang khas yaitu bersin, hidung beringus, hidung gatal, dan sumbatan pada hidung. ${ }^{6}$ Dermatitis atopi didiagnosis berdasarkan kriteria Hanifin dan Lobitz. ${ }^{7}$ Urtikaria adalah erupsi kulit yang berbatas tegas dan timbul (bentol), berwarna merah yang memutih bila ditekan dan disertai gatal. ${ }^{8}$ Diagnosis konjungtivitis yang termasuk ke dalam penelitian ini apabila terdapat konjungtivitis alergik ( hay fever), konjungtivitis vernalis, keratokonjungtivitis atopik, atau konjungtivitis giant papilar. ${ }^{9}$

Dicatat juga apabila terdapat sinusitis pada pasien asma yang didiagnosis oleh dokter ahli THT dengan pemeriksaan penunjang radiologi foto sinus paranasalis. Sinusistis adalah inflamasi mukosa sinus paranasal yang disebabkan oleh proses infeksi atau bukan infeksi. ${ }^{10}$

\section{Hasil}

Jumlah pasien asma yang berobat pada kurun waktu penelitian tercatat 275 orang, jumlah rekam medik yang ditemukan 215 (78,18\%), 67 (24,36\%) tidak diikutsertakan dalam penelitian karena data tidak lengkap. Jumlah akhir yang dimasukkan ke dalam penelitian 148 orang.

Rerata umur pasien 58 bulan ( 4 tahun 10 bulan), dengan umur terendah 4 bulan dan umur tertinggi 222 bulan (18 tahun 6 bulan). Rerata onset asma umur 32,7 bulan. Data karakteristik pasien tertera pada Tabel 1. Riwayat asma pada ayah terdapat pada 12 pasien $(11,6 \%)$ dan riwayat asma pada ibu $25(24,2 \%)$ dari 103 anak yang mempunyai riwayat atopi keluarga.

Pasien asma yang pernah mengalami penyakit alergi lain 88 orang (59,5\%) (Gambar 1). Rinitis alergi merupakan penyakit alergi yang terbanyak pada pasien asma yaitu sebanyak 39 (26,3\%). Penyakit alergi lain adalah dermatitis atopi, urtikaria, dan konjungtivitis.

Uji tusuk kulit dilakukan terhadap $64(43,2 \%)$ pasien. Hasil dari uji menemukan bahwa alergen yang terbanyak adalah tungau debu rumah sebanyak 46 orang $(71,9 \%)$ (Gambar 2).

Tabel 1. Data karakteristik pasien

\begin{tabular}{lcc}
\hline \multicolumn{1}{c}{ Variabel } & Jumlah & $\%$ \\
\hline $\begin{array}{l}\text { Jenis kelamin } \\
\text { - Laki-laki }\end{array}$ & & \\
- Perempuan & 83 & 56 \\
Riwayat atopi keluarga & 65 & 44 \\
- Ayah & & \\
- Ibu & 35 & 34 \\
- Saudara kandung & 68 & 66 \\
- Orang tua ayah & 24 & 23,3 \\
- Orang tua ibu & 27 & 26,2 \\
\hline
\end{tabular}

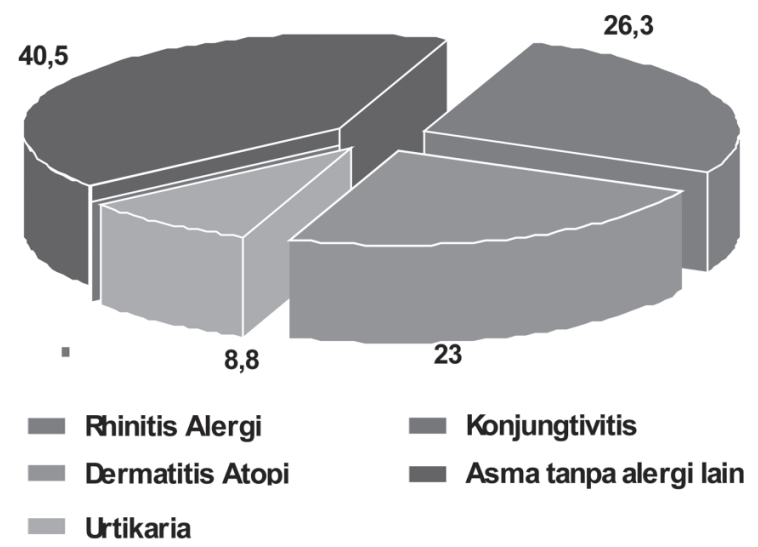

Gambar 1. Penyakit alergi lain pada anak dengan asma 


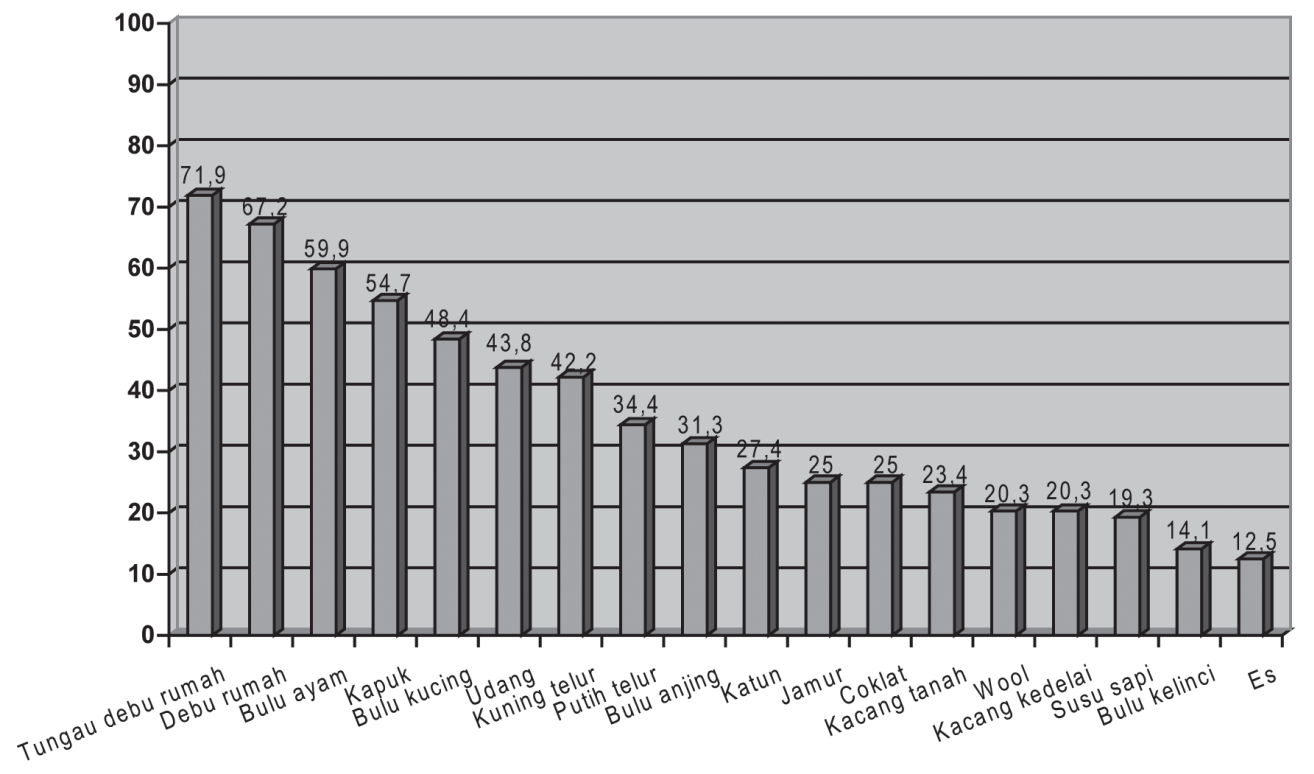

Gambar 2. Hasil uji tusuk kulit anak dengan asma

\section{Diskusi}

Definisi asma pada anak masih kontroversial. Definisi asma bervariasi tergantung pada tujuan dan memasukkan pandangan dari ahli epidemiologi, klinisi, ahli imunologi, ahli fisiologi dan ahli patologi. ${ }^{12}$ Definisi menurut Global Initiative for Asthma (GINA), asma adalah gangguan inflamasi kronik pada saluran napas dengan berbagai sel yang berperan, khususnya sel mast, eosinofil dan limfosit T. Pada individu yang rentan inflamasi, menyebabkan episode mengi yang berulang, sesak napas, dada terasa tertekan, dan batuk khususnya malam atau dini hari. Gejala ini berhubungan dengan penyempitan jalan napas yang luas dan bervariasi dengan sifat sebagian reversibel baik secara spontan maupun dengan pengobatan. Inflamasi ini juga berhubungan dengan hiperreaktivitas jalan napas terhadap berbagai rangsangan. ${ }^{2}$ Batasan tersebut sangat lengkap namun dalam penerapan klinis untuk anak tidak praktis, sehingga para perumus konsensus internasional dalam pernyataan ketiganya tetap menggunakan definisi lama yaitu mengi berulang dan atau batuk persisten, sedangkan sebab lain yang lebih jarang telah disingkirkan. ${ }^{13}$ Sebagian besar klinisi setuju bahwa kriteria yang penting dan cukup untuk diagnosis asma adalah episode obstruksi jalan napas berulang dengan manifestasi mengi atau batuk, gejala membaik dengan bronkodilator inhalasi atau pemberian steroid sistemik, dan fungsi paru yang normal diantara serangan. ${ }^{14}$

Hubungan asma dengan jenis kelamin merupakan suatu yang kompleks, lebih dari 60\% asma sebelum masa pubertas adalah laki-laki dan perbedaan ini diobservasi dari tahun pertama kehidupan. Faktor yang menentukan peningkatan risiko asma pada anak lakilaki masih belum dimengerti. ${ }^{15}$ Pada penelitian ini didapatkan anak laki-laki lebih banyak dari anak perempuan yaitu $56 \%$ dibanding $44 \%$.

Beberapa penelitian epidemiologis melaporkan bahwa riwayat ibu dengan asma berhubungan dengan risiko terjadinya asma pada anak. Dikemukakan bahwa sifat atopi dari ibu secara langsung mempengaruhi perkembangan sistem imun janin. ${ }^{15}$ Dari penelitian ini ditemukan juga riwayat asma pada ibu lebih banyak dari pada ayah dengan perbandingan 2:1.

Ditemukan rinitis alergi merupakan penyakit alergi terbanyak yang pernah dialami pasien asma pada penelitian ini. Pada sebuah penelitian case-control didapatkan bahwa rinitis merupakan faktor risiko terjadinya asma pada saat dewasa terhadap anak yang atopi ataupun tidak mempunyai riwayat atopi. ${ }^{16}$ Menurut rekomendasi dari Allergic Rhinitis and its Impact on Asthma (ARIA), pasien dengan rinitis alergi persisten sebaiknya dievaluasi secara seksama untuk 
mengetahui adanya asma dan sebaliknya pasien asma juga dievaluasi untuk mengetahui adanya rinitis alergik. $^{7}$

Atopi atau predisposisi genetik untuk memproduksi IgE spesifik setelah pajanan alergen, merupakan komponen dari penyakit atopi seperti asma, rinitis alergi, alergi makanan, dan dermatitis atopi. ${ }^{16,17}$ Faktor lingkungan memegang peran penting dalam memulai sensitisasi pada seseorang yang mempunyai bakat alergi. Proses sensitisasi terhadap alergen merupakan proses berkelanjutan sejak masa awal kehidupan. Faktor lingkungan yang mempengaruhi dapat merupakan faktor lingkungan pranatal dan pasca natal. ${ }^{17}$ Penelitian di Amerika Serikat dan beberapa negara lain membuktikan bahwa ada hubungan antara alergi terhadap debu rumah dan asma pada anak. Mengawasi keadaan lingkungan dengan mengurangi paparan terhadap debu rumah akan mengurangi risiko terjadinya asma. Penelitian prospektif di Inggris mengukur kadar protein tungau debu rumah mendapatkan bahwa derajat paparan protein tungau debu rumah semasa bayi mempercepat timbulnya gejala asma. ${ }^{16}$ Pada peneltian ini sensitisasi dilihat dari uji kulit (skin prick test) didapatkan uji positif terhadap alergen hirup menempati 5 urutan pertama dari 18 jenis alergen, dan tungau debu rumah mempunyai nilai paling tinggi diikuti oleh debu rumah, bulu ayam, kapuk dan bulu kucing.

Selama abad ke-20 dicatat insidens sinusitis tinggi pada anak maupun dewasa. Pada penelitian telah diketahui insidens radiografi sinus yang abnormal pada anak dengan mengi yang menetap. Pasien asma mempunyai foto sinus abnormal antara $31 \%-53 \% .^{5}$ Sinusitis merupakan komplikasi infeksi saluran napas atas, rinitis alergik, polip hidung dan kelainan lain yang menimbulkan sumbatan hidung. Sinusitis akut atau kronis dapat memprovokasai terjadinya asma. ${ }^{2}$ Hubungan asma dengan sinusitis telah diketahui dan dijelaskan pada literatur medis lebih dari 70 tahun. Hampir $80 \%$ pasien asma menderita rinitis alergi dan lebih dari 50\% pasien dengan sinusitis juga menderita asma. ${ }^{18,19}$ Pasien sinusitis yang kami temukan 9 orang $(6,1 \%)$, lebih rendah dari angka yang dilaporkan penelitian lain, keadaan ini mungkin disebabkan tidak semua pasien pada penelitian ini dilakukan foto sinus. Foto sinus hanya dilakukan pada pasien yang dicurigai sinusitis secara klinis. Pemeriksaan penunjang yang lebih baik terhadap sinusitis adalah skintigrafi sinus para nasal. ${ }^{20}$
Dari penelitian ini disimpulkan bahwa penyakit alergi lain yang pernah dialami anak dengan asma adalah rinitis alergik, dermatitis atopi, urtikaria, dan konjungtivitis. Disarankan penelitian lebih lanjut tentang hubungan rinitis serta sinusitis dengan asma.

\section{Daftar Pustaka}

1. Akib AAP. Perjalanan penyakit alergi dalam upaya pencegahannya. Dalam: Akib AAP, Tumbaleka AR, Matondang CS, penyunting. Pendekatan imunologis berbagai penyakit alergi dan infeksi. Naskah lengkap PKB Ilmu Kesehatan Anak XLIV. Jakarta: FKUI; 2000. h. 117-27.

2. Sing $\mathrm{H}$. The link between allergic rhinitis and other allergic diseases. Medical Progress, 2002:15-9.

3. Global initiative for asthma. Global strategy for asthma management and prevention. National Institutes of Health, Januari 1995, (direvisi 2002).

4. Simon RA. The allergy-asthma connection. Allergy and Asthma Proc 2002; 23:219-22.

5. Corren J, Rachelefsky. Upper airway disease and asthma. Dalam: Naspitz CK, Szeler SJ, Tinkelman D, Warner JO, penyunting. Textbook of pediatric asthma. London: Martin Duniz; 2001. h. 223-35.

6. Bosquet J, Cauwenberge P, Khaled N, Maesano IA, Bachert C, Cagnani CB, dkk. Allergic rhinitis and its impact on asthma initiative (ARIA). A pocket guide for physicians and nurses, 2002:1-13.

7. Santoso H. Dermatitis atopi. Dalam: Akib AAP, Matondang CS, penyunting. Buku ajar alergi imunologi anak. Jakarta: BP IDAI; 1996. h. 161-72.

8. Matondang CS. Urtikaria. Dalam: Akib AAP, Matondang CS, penyunting. Buku ajar alergi imunologi anak. Jakarta: BP IDAI; 1996. h. 154-60.

9. Shapiro GG, Rachelefsy GS. Introduction and definition of sinusitis. J Allergy Clin Immunol 1992; 90:417-18.

10. Siregar SP. Penyakit alergi pada konjungtiva dan kornea.Dalam: Akib AAP, Matondang CS, penyunting. Buku ajar alergi imunologi anak. Jakarta: BP IDAI; 1996. h. 200-3.

11. Parkin P, Goggin N. Asthma. Dalam: Feldmen E, penyunting. Evidence based pediatrics. London: BC Decker; 2000. h. 123-53.

12. UKK Pulmonologi PP IDAI. Pedoman Nasional Penanganan Asma Anak. Disampaikan pada temu ahli respirologi anak IV, Medan 5 April 2003. 
13. Sherman J. Can we prevent asthma? J Pediat Obstet Gynecol, Nov/Dec 2002; 13-18.

14. Martinez FD. Risk factors for development of asthma. Dalam: Naspitz CK, Szeler SJ, Tinkelman D, Warner JO, penyunting. Textbook of pediatric asthma. London: Martin Duniz; 2001. h. 673-79.

15. Slavin GR.Asthma and sinusitis. J Allergy Clin Immunol 1992; 90:534-7.

16. Gern JE, Lemanske RF. Pediatric allergy can it prevented? Immunol Allergy Clin North Am 1999; 19:233-52.

17. Samet JM, Wiesch DG, Ahmed IH. Pediatric asthma; epidemilogy and natural history. Dalam: Naspitz CK,
Szeler SJ, Tinkelman D, Warner JO, penyunting. Textbook of pediatric asthma. London: Martin Dunitz; 2001. h. 35-66.

18. Brinke AT, Grootendorst DC, Schmit JT, Bruinei FT, van Buchem MA, Strck PJ, dkk. Chronic sinusitis in severe asthma is related to sputum eosinophilia. J Allergy Clin Immunol 2002; 109:621-6.

19. Guerra S, Sherril DL, Martinez FD, Barbee RA. Rhinitis as an independent factor for adult asthma onset. J Allergy Clin Immunol 2002; 109-25.

20. Campanella SG, Asher MI. Current controversies: Sinus disease and lower airways. Pediatr Pulmonol 2001; 31:165-72. 